\title{
KAJIAN PERAN GEN P53 DALAM TUMORIGENESIS
}

\author{
Retina Yunani \\ Laboratorium Farmakologi dan Farmasi, Fakultas Kedokteran Hewan \\ Universitas Wijaya Kusuma Surabaya \\ Email: retina_yunani@yahoo.com
}

\begin{abstract}
Gene p53 is a tumor suppressor gene that in normal conditions is in 'standby ' mode, several studies show that pivotal point that lead to stimulation of p53 is DNA damage, heat shock, hypoxia, exposure of nitric oxide ( $N O$ ), the expression of oncogenes and some p53 pathways activation. p53 mechanism as a guardian of genome stability are cell cycle arrest, repair of DNA damaged, induce apoptosis, prevents angiogenesis, invasion and metastasis ability of the tumor. On many tumor, p53 is not loss, but mutated, the p53 mutant was expressed $70 \%$ in lung cancer, and in different frequencies in other cancers. Then the role of p53 as a transcription factor that works to regulate genes involved in tumor suppression is indispensable .
\end{abstract}

Keyword: Gene p53, Nitric oxide, DNA

\section{PENDAHULUAN}

Protein p53 pertama kali diidentifikasi pada tahun 1979 sebagai protein yang terkait dengan proses transformasi sel dan merupakan protein yang banyak terakumulasi didalam nukleus sel kanker. Gen yang mengkode p53 awalnya ditemukan memiliki sifat onkogenik hal tersebut dikarenakan p53 banyak diekspresikan pada sel tumor baik pada manusia dan tikus (Bay dan Zhu,2006). Tetapi 10 tahun kemudian tim yang dipimpin oleh Bert Vogelstain dan Ray White menemukan pada kejadian kanker kolon bahwasannya p53 merupakan tumor suppressor gene (George, 2011). Dengan perannya sebagai tumor suppressor gene telah menjadikan p53 sebagai subyek dibanyak penelitian yang berkenaan dengan terapi antikanker. Seekor mencit yang dihilangkan protein p53nya akan dapat hidup normal tetapi mencit tersebut akan sangat rentan terhadap pertumbuhan tumor. Mutasi p53 ditemukan pada banyak kejadian kanker, mutasi p53 pada kanker paru sekitar $70 \%$, pada kanker kolon, kepala dan leher, ovarium, kandung kemih $60 \%$ dan pada kanker saluran cerna sebanyak 45\% (Hollstain et al, 1991; Vogelstein et al, 2000; Sherr,1998), karena kebanyakan tumor memiliki mutasi pada gen p53 atau cacat fungsional dalam p53 pathway maka peran p53 sebagai penjaga integritas tumor sangat penting dalam pencegahan tumorigenesis. Struktur protein $\mathbf{p 5 3}$

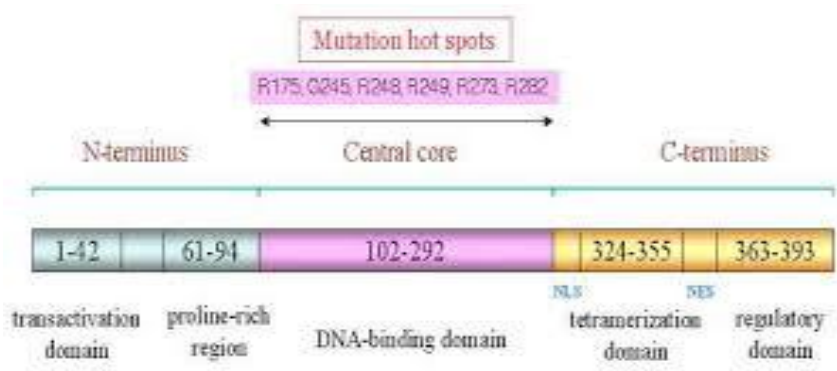

Gambar 1. Struktur protein p53 (Bay dan Zhu, 2006)

Gen p53 merupakan nuclear phosphoprotein dengan berat molekul $53 \mathrm{kDa}$, dikode oleh $20-\mathrm{Kb}$ gen, terdiri atas 11 ekson dan 10 intron, berlokasi pada lengan pendek kromosom 17 (Isobe et al, 1986). Protein p53 terdiri atas 393 asam amino dengan beberapa domain structural dan fungsional. N-terminal domain terdiri atas amino-terminal domain (residu 1-42) dan proline -rich region (residu 61-94), central core domain (residu 102-292) 
(Slee et al, 2004; Bode et al, 2004; Voesden et al, 2002) dan C-terminal domain (residu 301393) yang terdiri atas oligomerization domain (residu 324-355) dan carboxyl-terminal regulatory domain (residu 363-393).

Amino terminal domain berperan pada proses interaksi dengan faktor transkripsi (Field et al, 1990; Lin et al, 1994). Proline-rich region menjaga stabilitas p53, tanpa proline-rich region akan menyebabkan p53 rentan terhadap proses degradasi (Sakamuro,1997). Central-core domain adalah region yang sering mengalami mutasi pada sel kanker dan jaringan tumor. $C$ terminal domain berfungsi dalam induksi kematian sel (Chen et al, 1996)

\section{p53 dalam cell cycle arrest dan perbaikan kerusakan DNA}

Dalam kondisi normal p53 berada dalam 'standby' mode. Beberapa kondisi akan mengakibatkan teraktivasinya p53 diantaranya adalah kerusakan DNA dan komponen materi genetiknya, hipoksia, heat shock, paparan nitric oxide (NO), ekspresi onkogen dan beberapa jalur aktivasi p53 (George, 2011; Gasco, 2002). Kerusakan DNA akan mengaktifkan protein kinase seperti ataxia-telangectasia mutated (ATM), DNA-PK atau human homologue of Rad 53 (CHK2) yang kemudian akan memfosforilasi p53 pada residu Ser 15, Thr 18 atau Ser 20 sehingga jumlah p53 mengalami peningkatan dikarenakan penurunan mouse double minute 2 (MDM2),MDM2 memiliki peran kunci dalam regulasi protein p53, MDM2 adalah produk onkogen yang memperantarai beberapa kejadian kanker (George, 2011). Dari proses fosforilasi yang berdampak kenaikan jumlah p53, afinitas p53 juga semakin tinggi terhadap DNA, p53 melakukan fungsinya untuk memperbaki kerusakan DNA, setelah DNA berhasil diperbaiki ATM kinase menjadi tidak aktif, p53 didefosforilasi dan didegradasi oleh MDM2, sehingga sel kembali lagi pada kondisi normal(Gasco, 2002).

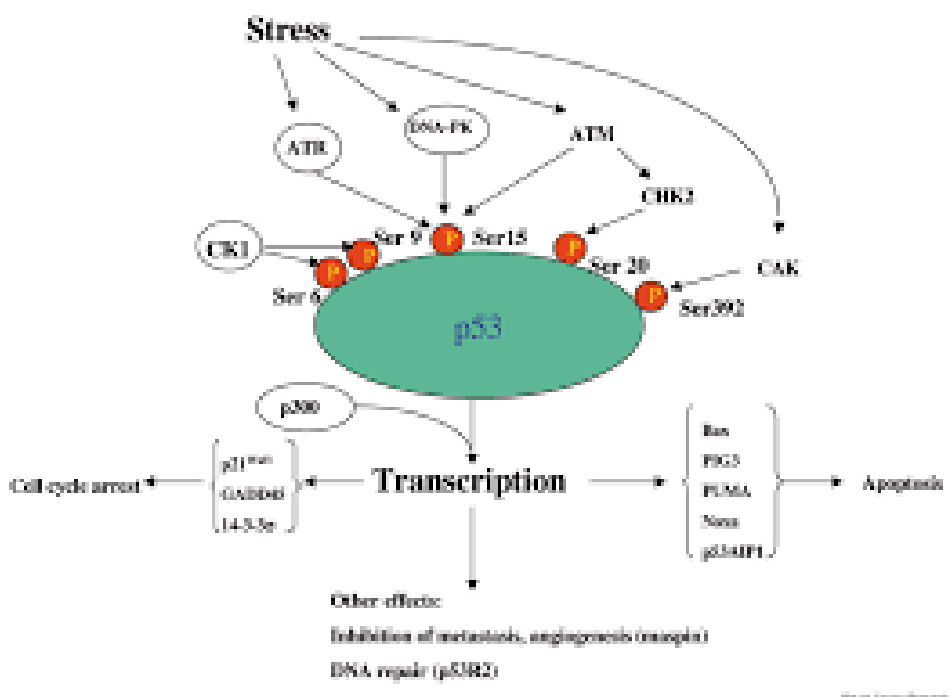

Gambar 2. Cell Cycle arrest (Gasco et al, 2002)

Respon terhadap kerusakan DNA yang menyebabkan akumulasi protein p53 juga menghasilkan mekanisme cell-cycle arrest, yaitu pada fase $\mathrm{G} 1$, fase sebelum terjadinya replikasi DNA, atau pada fase G2, yaitu fase sebelum terjadinya mitosis. Proses cell cycle arrest tersebut akan memberikan kesempatan bagi sel untuk melakukan beberapa proses enzimatis untuk perbaikan sel, sehingga akan menghindarkan transmisi informasi genetik yang salah dari satu generasi sel ke generasi selanjutnya. Pada sel yang mengekspresikan mutant p53 proses cell-cycle arrest tidak terjadi, meskipun terjadi kerusakan DNA (Kuerbitz, 1992). Mekanisme cell-cyle arrest oleh p53 diawali dengan terikatnya p53 dengan factor transkripsi yang disebut E2F, sehingga menyebabkan E2F tidak dapat berikatan dengan protooncogen promoter seperti c-myc dan c-fos. Transkripsi c-myc dan c-fos diperlukan pada saat mitosis untuk menghentikan faktor transkripsi yang berperan menghentikan pembelahan sel (George, 2011). Jadi dengan adanya ikatan p53 dengan faktor transkripsi E2F, berarti c-myc dan c-fos tidak mampu untuk menghentikan kerja dari faktor transkripsi yang berperan dalam cell-cycle arrest.

p53 sebagai factor transkripsi juga bekerja untuk menekan atau memunculkan ekspresi gen yang terlibat dalam cell-cycle, salah satu yang memiliki peran penting adalah p21. Produk gen p21 adalah penekan aktifitas cyclin-dependent kinase, enzim penting pada 
proses cell-cycle yang meghasilkan pembelahan sel. Dengan menstimulasi transkripsi gen p21 oleh p53 maka berhentinya proliferasi sel dapat terjadi, hal ini dapat dibuktikan dari penelitian Barboza et al (2006) yang memperlihatkan bahwa pemberian mutan p53 pada $p 21$ null mice menimbulkan hilangnya respon cell cycle arrest dan peningkatan tumorigenistas. Yang menarik dari respon aktivasi p53 pada carcinoma dan sarcoma adalah dihasilkannya mekanisme cell cycle arrest dibandingkan aktivasi mekanisme apoptosis. Meskipun penelitian kultur jaringan menunjukkan bahwa cell cycle arrest bersifat sitostatik dan menimbulkan stabilisasi penyakit dibandingkan menginduksi regresi, ternyata hasil menggembirakan didapatkan dari hasil penelitian in vivo bahwa mekanisme cell cycle arrest selanjutnya melibatkan sistem kekebalan tubuh sehingga menghasilkan tumor clearance (Xue et al, 2007)

\section{p53 dalam induksi apoptosis}

Banyak penjelasan mengenai fungsi p53 menyatakan bahwa induksi apoptosis adalah mekanisme kunci yang menyebabkan kematian sel kanker. Penelitian yang dilakukan oleh Toledo et al (2006) memperlihatkan bahwa mencit yang mengekspresikan mutan protein p53 kurang memiliki kemampuan dalam menginduksi cell cycle arrest tetapi masih mampu menginduksi apoptosis sehingga dapat mencegah perkembangan tumor. Pada peristiwa apoptosis, PUMA (p53-upregulated modulator of apoptosis) mediator kunci apoptosis melalui mitochondrial pathway, memaikan peran yang sangat penting, hal ini bisa dilihat dari penelitian $\mathrm{Yu}$ dan Zhang (2003) yang menggunakan PUMA null mice, memperlihatkan bahwa p53 tidak bisa bekerja dalam peristiwa apoptosis di banyak jaringan tanpa keberadaan PUMA sebagai sebagai modulator apoptosisnya, senada dengan temuan Garrison et al (2008) bahwa tanpa PUMA, tumorigenesis yang diinduksi oleh myc ancogen semakin meningkat.

Sebagai penjaga gerbang sel salah satu peran p53 adalah untuk memonitor stres sel dan menginduksi apoptosis apabila diperlukan. Didalam jaringan dimana stres menghasilkan kerusakan yang luas dan irreversible, p53 dapat memulai apoptosis. Produk gen apoptosis yang diinduksi oleh p53 diantaranya adalah Bax ( $\mathrm{Bcl}$
- 2 associated X protein ), DR5 / KILLER ( death receptor 5 ), Dral, Fas / CD95 (cell-death signaling receptor), PIG3 (p53 - inducible gen 3), Puma (p53-upregulated modulator of apoptosis), Noxa (dari kata Latin untuk " bahaya " atau " kerusakan "), PIDD (p53-induced protein with death domain), PERP (p53 apoptosis effector related to PMP - 22 ), Apaf 1 ( apoptotic protease-activating factor-1), Scotin, p53AIP1 (p53-regulated apoptosisinducing protein 1) dan lain-lain (Bai dan Zhu, 2006)

Gen-gen tersebut akan menginduksi apoptosis dengan intrinsic pathway (mitochondrial pathway) atau dengan extrinsic pathway (death receptor pathway). Intrinsic apoptotic pathway berlangsung apabila terjadi stres sel. Gen yang mendominasi adalah kelompok protein Bcl-2 seperti Bax, Bid, Puma, Noxa, and p53AIP1 yang kemudian menempati mitokondria dan menimbulkan hilangnya potensial membran, kemudian sitokrom c, suatu molekul proapoptotic, dilepaskan dan menimbulkan terbentuknya komplek apoptosom dengan Apaf-1 dan caspase 9. Capcase 9 akan mengaktifkan downstream procaspase-3. Protein caspase 3 mempunyai kemampuan untuk mengaktifkan caspase lainnya, seperti procaspase-6 dan procaspase-7 yang memberikan amplifikasi terhadap kerusakan seluler. . Pada extrinsic pathway, p53 menginduksi apoptosis melalui aktivasi death receptor yang terdapat pada plasma membran, diantaranya adalah Fas/CD95, DR4 dan DR5, sehingga menimbulkan hambatan produksi IAPs(inhibitor of apoptosis proteins). Baik DR5 and DR4 dapat memicu atau menginduksi apoptosis melalui TRAIL (tumor necrosis factor-related apoptosis-inducing ligand), Fas ligand dan agen kemoterapi. p53 juga dapat menginduksi apoptosis via endoplasmic reticulum-dependent mechanism dengan cara mengaktivasi ekspresi Scotin, protein yang berlokasi di endoplasmic reticulum dan nuclear membran (Bai dan Zhu, 2006)

\section{p53 sebagai penghambat angiogenesis dan metastasis}

Pada sebagian besar kejadian tumor pada manusia, p53 tidak hilang melainkan mengalami point mutation sehingga 
menghambat kemampuannya dalam berikatan dengan DNA, sebagai faktor transkripsi dan tumor suppression, mutan p53 yang diekspresikan pada sel kanker juga dikaitkan dengan tumorigenesis, invasi dan metastasis (Oren dan Rotter, 2010). Menurut Wang et al (2009) dan Kogen-Sakin et al (2010), mutan p53 dapat mengatur gen yang terlibat dalam migrasi sel baik secara langsung maupun tidak langsung, mutan p53 diperantarai Slug atau Twist, suatu factor transkripsi yang mengatur perkembangan embrionik pada epithelial-mesenchymal transition (EMT) (Shiota et al, 2008) dapat menginduksi EMT yang bersifat parsial sehingga menyebabkan supresi sintesis Ecadherin, hilangnya E-cadherin sering dikaitkan dengan kejadian metastasis pada kanker (Derksen et al, 2006), supresi anti-invasive gene CCN-S/WISP2 juga bisa menimbulkan metastasis (Dhar et al, 2008), selain itu RhoA / ROCK (Rho-associated coiled-coil containing protein kinase) signalling dapat menginisiasi amoeboid migratory mode yang menyebabkan sel kanker menginvasi stroma.

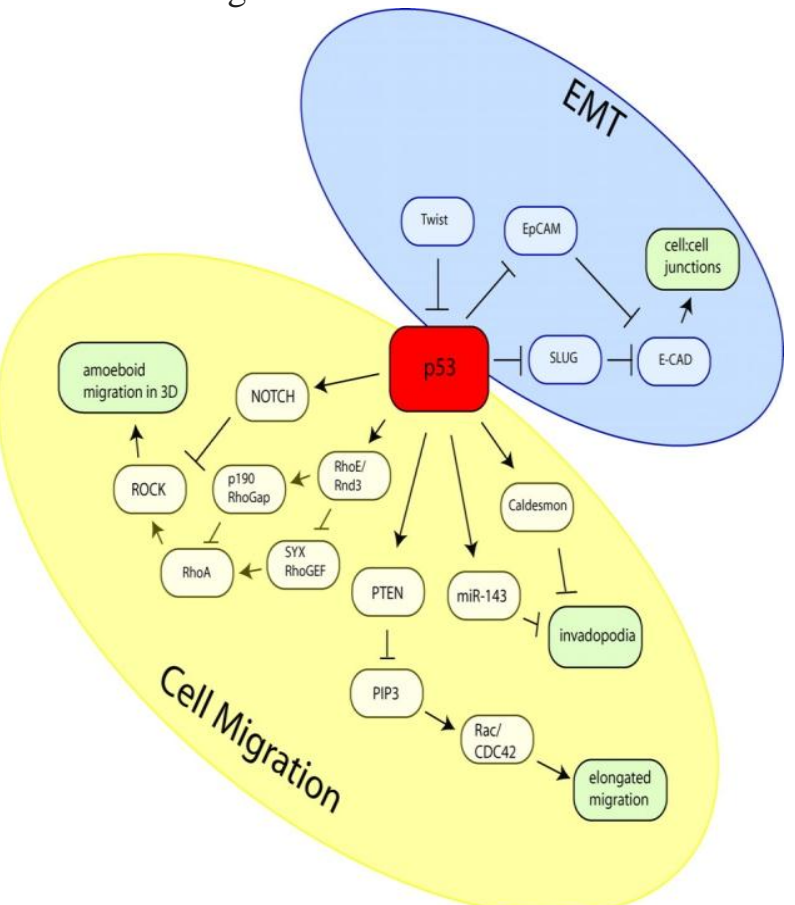

Gambar 3. p53 menekan migrasi sel yang mendukung metastasis (Muller et al, 2011)

Pada kanker payudara Transducer of Cdc-42-dependent actin assembly-1 (Toca-1) berfungsi untuk merekrut actin regulatory protein sehingga terjadi invadopodia yang menyebabkan meningkatnya kemampuan metastasis tumor, ketika p53 kehilangan fungsinya dikarenakan beberapa sebab, maka ekspresi Toca-1 meningkat, maka mengembalikan fungsi p53 dapat menekan terjadinya metastasis dan daya invasi tumor(Chander et al,2014) . p53 juga dapat menghambat angiogenesis dengan cara menghambat produksi faktor proangiogenesis seperti VEGF dan meningkatkan produksi TSP yang bersifat antiangiogenik (Teodoro et al, 2007). p53 juga menginduksi faktor angiogenik yang berasal dari kolagen yaitu endostatin dan tumstatin (Teodoro et al, 2006), hal ini dapat dibuktikan bahwa mencit yang tidak mengekspresikan perkursor tumstatin, $\alpha 3$ collagen 4 menunjukkan peningkatan pertumbuhan tumor (Hamano et al, 2003)

\section{KESIMPULAN}

Pada banyak kejadian tumor, yang terjadi bukanlah disebabkan karena hilangnya p53 melainkan disebabkan karena terjadinya mutasi pada p53 sehingga beberapa fungsinya tidak berjalan sebagaimana mestinya. Fungsi p53 berkenaan dengan tumorigenesis salah satunya adalah cell cycle arrest yang memberikan kesempatan pada sel dengan kerusakan DNA untuk melakukan perbaikan diri, sehingga tidak mentransfer informasi genetic yang salah dari satu generasi sel ke generasi berikutnya, cell cyle arrest terjadi melalui supresi p21, suatu faktor transkripsi yang diregulasi oleh p53. Apoptosis melalui mekanisme intrinsic pathway dan extrinsic pathway melibatkan beberapa gen yang diinduksi oleh p53, salah satunya adalah Puma, pada beberapa penelitian ketiadaan Puma akan meningkatkan resiko tumorigenesis. Yang terakhir adalah fungsi p53 sebagai antiangiogenesis, antiinvasif dan antimetastatik dapat digunakan pada tumor dengan mutan p53 yang sering dikaitkan dengan tumorigenesis, invasi dan metastasis.

\section{DAFTAR PUSTAKA}

Barboza, J.A., Liu, G., El-Naggar, A.K., and Lozano, G. 2006. p21 delays tumor onset by 
preservation of chromosomal stability. Proc. Natl. Acad. Sci. USA 103, 19842-19847.

Bai, L and W.G. Zhu.2006. p53: Structure, Function and Therapeutic Apllications. Journal of Cancer Molecules 2(4): 141-153

Bode AM, Dong Z. 2004.Post-translational modification of p53 intumorigenesis. Nat Rev Cancer 4: 793-805.

Chander H, Halpern M, Resnick-Silverman L, Manfredi JJ, Germain D. 2011.Skp2B overexpression alters a prohibitin-p53 axis and the transcription of PAPP-A,the protease of insulin-like growth factor binding protein 4 . PLoS One;6:e22456.

Chen X, Ko LJ, Jayaraman L, Prives C. 1996.p53 levels, functional domains, and DNA damage determine the extent of the apoptotic response of tumor cells. Genes Dev 10: 24382451.

Derksen, P.W., X. Liu, F. Saridin, H. van der Gulden, J. Zevenhoven, B. Evers, J.R. van Beijnum, A.W. Griffioen, J. Vink, P. Krimpenfortl. 2006. Somatic inactivation of E-cadherin and p53 in mice leads to metastatic lobular mammary carcinoma through induction of anoikis resistance and angiogenesis. Cancer Cell. 10:437-449. doi:10.1016/j.ccr.2006.09.013

Dhar, G., S. Banerjee, K. Dhar, O. Tawfik, M.S. Mayo, P.J. Vanveldhuizen, and S.K. Banerjee. 2008. Gain of oncogenic function of p53 mutants induces invasive phenotypes in human breast cancer cells by silencing CCN5/WISP-2. Cancer Res. 68:4580-4587. doi:10.1158/0008-5472.CAN- 08-0316

Fields S, Jang SK.1990. Presence of a potent transcription activating sequence in the p53 protein. Science 249: 1046-1049.

Gasco M, S. Shami and T. Crook. 2002.The p53 pathway in breast cancer. Breast cancer research. Vol 44 No.2

Garrison, S.P., Jeffers, J.R., Yang, C., Nilsson, J.A., Hall, M.A., Rehg, J.E., Yue, W., Yu,
J.,Zhang, L., Onciu, M.,. 2008. Selection against PUMA gene expression in Myc-driven B cell lymphomagenesis. Mol. Cell. Biol. 28, 53915402.

George, P.2011.p53 How crucialis its role in cancer. International Journal of Current Pharmaceutical Research. Vol.3 Issue. 2

Hamano Y, Zeisberg M, Sugimoto H, Lively JC, Maeshima Y, Yang C. 2003.Physiological levels of tumstatin, a fragment of collagen IV alpha3 chain, are generated by MMP-9 proteolysis and suppress angiogenesis via alphaV beta 3 integrin. Cancer Cell;3:589-601.

Hollstein M, Sidransky D, Vogelstein B, Harris CC.1991. p53 mutations in human cancers. Science 253: 49-53.

Isobe M, Emanuel BS, Givol D, Oren M, Croce CM.1986. Localizationof gene for human p53 tumour antigen to band $17 \mathrm{p} 13$. Nature320: $84-$ 85.

Kogan-Sakin, I., Y. Tabach, Y. Buganim, A. Molchadsky, H. Solomon, S. Madar, I. Kamer, P. Stambolsky, A. Shelly, N. Goldfinger, et al. 2010. Mutant p53(R175H) upregulates Twist1 expression and promotes epithelialmesenchymal transition in immortalized prostate cells. Cell Death Differ. In press.

Kuerbitz, S.J., B.S. Plunkett, W.V. Walsh, M.B. Kastan. 1992. Wild-type p53 is a cell cycle checkpoint determinant following irradiation. Proc. Natl. Acad. Sci. USA 89: 7491-7495.

Muller, P.A.J., K.H. Vousden., J.C. Norman.2011. p53 and its mutants in tumor cell migration and invasion. J Cell Biol. Vol 192 No.2: 209-218

Lin J, Chen J, Elenbaas B, Levine AJ.1994. Several hydrophobic amino acids in the p53 amino-terminal domain are required for transcriptional activation, binding to $\mathrm{mdm}-2$ and the adenovirus

5 E1B 55-kD protein. Genes Dev 8: 1235-1246. 
Oren, M., and V. Rotter. 2010. Mutant p53 gain-of-function in cancer. Cold Spring Harb. Perspect. Biol. 2:a001107. doi:10.1101/cshperspect.a001107

Sakamuro D, Sabbatini P, White E, Prendergast GC. 1997.The polyproline region of p53 is required to activate apoptosis but not growth arrest. Oncogene 15: 887-898.

Sherr CJ. 1998.Tumor surveillance via the ARFp53 pathway. Genes Dev 12: 2984-299.

Shiota, M., H. Izumi, T. Onitsuka, N. Miyamoto, E. Kashiwagi, A. Kidani, G. Hirano, M. Takahashi, S. Naito, and K. Kohno. 2008. Twist and p53 reciprocally regulate target genes via direct interaction. Oncogene. 27:5543-5553. doi:10.1038/onc.2008.176

Slee EA, O'Connor DJ, Lu X.2004. To die or not to die: how does p53decide? Oncogene 23: 2809-2818.

Teodoro JG, Parker AE, Zhu X, Green MR. 2006. p53-mediated inhibition of angiogenesis through up-regulation of a collagen prolyl hydroxylase. Science;313:968-71.

Teodoro JG, Evans SK, Green MR.2007. Inhibition of tumor angiogenesis by p53: a new role for the guardian of the genome. J Mol Med.

Toledo, F., Krummel, K.A., Lee, C.J., Liu, C.W., Rodewald, L.W., Tang, M., and Wahl, G.M. 2006. A mouse p53 mutant lacking the proline-rich domain rescues $\mathrm{Mdm} 4$ deficiency and provides insight into the Mdm2-Mdm4-p53 regulatory network. Cancer Cell 9, 273-285.

Vogelstein B, Lane D, Levine AJ. 2000.Surfing the p53 network. Nature 408: 307-310.

Vousden KH, Lu X.2002. Live or let die: the cell's response to p53. Nat Rev Cancer 2: 594604.

Wang, S.P., W.L. Wang, Y.L. Chang, C.T. Wu, Y.C. Chao, S.H. Kao, A. Yuan, C.W. Lin, S.C. Yang, W.K. Chan. 2009. p53 controls cancer cell invasion by inducing the MDM2-mediated degradation of Slug. Nat. Cell Biol. 11:694-704. doi:10.1038/ncb1875

Xue, W., Zender, L., Miething, C., Dickins, R.A., Hernando, E., KrizhanovskyV., CordonCardo, C., and Lowe, S.W. 2007. Senescence and tumour clearance is triggered by p53 restoration in murine liver carcinomas. Nature $445,656-660$. 